Original scientific paper - Izvorni znanstveni rad

UDK: 637.112 .2

\title{
Changes of physico-chemical characteristics, somatic cell count and curd quality during lactation and their relationships in Lacaune ewes
}

doi: $10.15567 /$ mljekarstvo.2017.0206

\author{
Jan Kuchtík ${ }^{1}$, Leona Konečná ${ }^{1}$, Vladimír Sýkora ${ }^{1}$, Květoslava Šustová ${ }^{1}$, \\ Martin Fajman ${ }^{1}$, Ivica Kos ${ }^{2 *}$
}

${ }^{1}$ Mendel University in Brno, Faculty of AgriSciences, Zemědělská 1, Brno 613 00, Czech Republic ${ }^{2}$ University of Zagreb, Faculty of Agriculture, Svetošimunska 25, 10000 Zagreb, Croatia

Received - Prispjelo: 12.01.2017.

Accepted - Prihvaćeno: 06.04.2017.

\begin{abstract}
The aim of research was to evaluate changes of physico-chemical characteristics, somatic cell count and curd quality during lactation and their relationship in Lacaune ewes. The study was carried out on eighteen ewes of the second lactation on an organic farm in Valašská Bystřice (Czech Republic). It was found that the stage of lactation significantly affected almost all monitored traits except $\mathrm{pH}$ value, titratable acidity, somatic cell count and curd quality. The content of total solids, fat, total protein, casein, $\mathrm{Ca}$ and $\mathrm{P}$ was significantly increased, while daily milk yield and the content of lactose were decreasing with the advancement of lactation. The stage of lactation had a significant effect on the coagulation time that was extended with advanced lactation. Length of the coagulation time was positively correlated with contents of total protein, casein and Ca. In contrast, the curd quality was not affected by the stage of lactation and no significant correlation between the curd quality and other parameters were found, except for the coagulation time $(\mathrm{r}=0.40)$. It could be concluded that Lacaune ewes had a satisfactory milk yield and physico-chemical and technological characteristics of milk under relatively extensive nutrition.
\end{abstract}

Key words: sheep milk, lactation, chemical composition, technological properties, milk coagulation

\section{Introduction}

Dairy sheep represents a minority of livestock farming in the Czech Republic. However, a trend of gradually increasing number of dairy sheep has been registered in the last decade. Dairy sheep farms in the Czech Republic are mostly organic, the nutrition of sheep on these farms is relatively extensive, milk production is mostly seasonal and milk is largely processed directly on farms. The latest development of dairy sheep sector in the Czech Republic is mainly influenced by a growth of consumer interest in sheep cheese. Consumers of these products especially appreciate their specific taste as well as their natural and organic image. On the most of the Czech dairy sheep farms purebred Lacaune sheep or their crossbreeds with East Friesian sheep or Improved Wallachian sheep are reared. On some farms purebred Šumavská sheep are also milked.
The composition of sheep milk can be affected by numerous factors such as nutrition, season, stage of lactation, and year. It was found by some authors that during lactation the contents of total solids (TS), fat (F) and protein (TP) increase, while the lactose (L) content decreases (Novotna et al., 2009; Matutinovic et al., 2011). In contrast, Pugliese et al. (2000) reported that the lactose content tends to remain constant over the entire lactation. The contents of $\mathrm{Ca}$ and $\mathrm{P}$ are higher in sheep milk than in cow milk, and their content in sheep milk is mainly influenced by breed, nutrition and stage of lactation (Park et al., 2007). According to Polychroniadou and Vafopoulou (1985), the content of $\mathrm{Ca}$ in sheep milk is also affected by the contents of total protein and casein.

The most significant non-infectious factors that affect somatic cell count (SCC) in sheep milk are 
parity, stage of lactation, time of year, herd and handling of ewes (Paape et al., 2007; Matutinovic et al., 2011). Nevertheless, SCC is also a good indicator of the existence of subclinical mastitis; whereby, subclinical infection may result in significant losses of milk yield and changes in milk composition (Gonzalo et al., 2002; Leitner et al., 2004). In the United States the limit for sheep milk is below 1,000,000 SCC/mL (Paape et al., 2007); whereas in European Union there is no legal limit for this milk. Nevertheless, Bianchi et al. (2004) reported the limit for subclinical mastitis in sheep at level of 500,000 SCC/mL and Pirisi et al. (2007) stated that an incentive payment for sheep milk with lower SCC than $1,000,000 / \mathrm{mL}$ is used in Sardinia.

Sheep milk is richer in casein and fat, has better coagulation characteristics, forms firmer curds and shows less loss of solids in the whey than the cow or goat milk. These properties allow obtaining cheese with higher fat content and better sensory characteristics (Haenlein and Wendorff, 2008). Many different factors can affect milk coagulation properties and the curd quality (CQ), whereby, the most important ones are the contents of protein, casein, fat, $\mathrm{Ca}$ and $\mathrm{P}$ in milk, $\mathrm{pH}$ and titratable acidity of milk and SCC (Pellegrini et al., 1997; Jaramillo et al., 2008). However, changes in coagulation properties can be also affected by other factors such as animal genetic characteristics or health status (Coulon et al., 2004).

The aim of this study was to evaluate changes in physico-chemical characteristics, somatic cell count's and curd quality during lactation and their relationship in Lacaune ewes which were kept under relative extensive nutrition. The evaluation of daily milk yield (DMY) and coagulation time (CT) was an integral part of this study.

\section{Material and methods}

\section{Animals, nutrition, and experimental design}

The study was carried out on an organic farm in Valašská Bystřice, located in the Zlín region of the Czech Republic (the farm is situated at altitude of $570 \mathrm{~m}$ above sea level; mean annual temperature of $7.6{ }^{\circ} \mathrm{C}$; annual precipitation of $720 \mathrm{~mm}$ ). Eighteen ewes of Lacaune (LC) breed in the second lactation were involved in the experiment. The lambing occurred in the first half of March. Weaning of lambs was carried out at mean age of 54 days. After weaning (since May $1^{\text {st }}$ ), all ewes began to be machine milked twice a day. Within the milking season, the daily feed ration of ewes was relatively extensive and consisted of pasture (ad libitum), organic oat $(0.2 \mathrm{~kg} / \mathrm{ewe})$ and organic mineral lick (ad libitum). Throughout the whole study ewes were continuously kept on the pasture. Grass species composition of the pasture was evaluated at the beginning of the study using the method of estimation of ground cover of individual species. The dominant grass species were: Festuca rubra (L.) (23 \%), Lolium perenne (L.) (12 \%), Agrostis capillaris (L.) (10\%), Phleum pratense (L.) (8\%), and Poa pratensis (L.) (7\%). Stocking density of the pasture was 4 ewes/ha (0.6 LU/ha). During the experiment, all ewes were kept in one flock under identical conditions without any discernible differences in their nutrition or management. All ewes were also under permanent veterinary supervision.

\section{Milk recording and sampling}

Individual milk recording and sampling of each ewe were carried out once per month within the whole experimental period (from May to September, on the mean 57, 92, 127, 162 and 197 day of lactation). All lactating ewes were dried off in the mid October. Milk yield recording was carried out in the morning milking (6 a.m.) and in the evening milking (6 p.m.), while milk sampling was performed only in the morning milking. Individual milk samples (volume at least $250 \mathrm{~mL}$ ) were cooled to $5-8{ }^{\circ} \mathrm{C}$ and transported to the specialized milk laboratory at Mendel University in Brno and to the private Laboratory for Milk Analysis in Brno-Tuřany (Bohemian-Moravian Association of Breeders, a.s.).

\section{Milk analysis}

Total solids (TS) content was determined gravimetrically by oven drying at $102{ }^{\circ} \mathrm{C}$ to constant weight (Czech Technical Standard ISO No. 6731). Fat (F) content was determined by Gerber's acidobutyrometric method (Czech Technical Standard ISO No. 2446). Total protein (TP) and casein contents were determined using a PRO-MILK apparatus (Foss Electric, Denmark). Lactose (L) content was determined polarimetrically (Czech Technical Standard No. 570530). Calcium (Ca) content was 
determined by atomic absorption spectrometric method (Czech Technical Standard ISO No. 8070 (570519). Phosphorus (P) content was determined by method using molecular absorption spectrometry (Czech Technical Standard ISO No. 9874 (570523). $\mathrm{Ca} / \mathrm{P}$ ratio was calculated from the $\mathrm{Ca}$ and $\mathrm{P}$ content. Active acidity $(\mathrm{pH})$ was measured with the pH-meter WTW 95 with the probe WTW SenTix 97. Titratable acidity (TA) was determined by titration using the Soxhlet-Henkel method (Czech State Standard No. 570530). SCC was determined using fluoroopto-electronic apparatus BENTLEY 2500 (Czech State Standard EN ISO No. 13366-2).

\section{Coagulation time and curd quality}

Milk samples $(100 \mathrm{~mL})$ were kept in Erlenmeyer flask at $35{ }^{\circ} \mathrm{C}$ for 10 minutes using a water bath with $\pm 0.05{ }^{\circ} \mathrm{C}$ temperature accuracy. For renneting was used commercial chymosin liquid rennet Laktochym (Milcom a.s., Tábor, Czech Republic), the rennet strength was 1:5,000. The rennet solution was obtained by diluting $10 \mathrm{~mL}$ of Laktochym and $40 \mathrm{~mL}$ of distilled water. The coagulation time (in seconds) was the time from application of rennet solution to the first appearance of small visual flocs. The renneted milk was subsequently placed in a tempered thermostat $\left(35^{\circ} \mathrm{C}\right)$ for 60 minutes. Thereafter the rennet curd was placed in a Petri dish and curd quality (CQ) was evaluated according to the appearance and firmness of the curd and the appearance of the whey, as described in Table 1.

\section{Statistical analyses}

Statistical analysis was performed using the STATISTICA software, version 12. ANOVA. Analysis was used to study the differences in the physicochemical properties, SCC, CT and CQ in the course of lactation. Sheffe's test was used as post-hoc analyses to identify individual significant contrasts within the lactation stage. Pearson's correlation was carried out to asses a level of the correlation coefficient among all particular variables. The differences were considered significant if $\mathrm{p}<0.05$.

\section{Results and discussion}

The stage of lactation had a significant effect on the daily milk yield (DMY) and content of all monitored basic components of milk (Table 2). These findings are consistent with data published by Aganga et al. (2002), Sevi et al. (2004) and Matutinovic et al. (2011). The DMY of ewes gradually decreased during lactation (except in 162 day), which could be related to lactation advancement and changes in pasture quality during the study. By contrast, Antunac et al. (2011) and Hernandez et al. (2014) found that the peak of the DMY occurred in the middle of lactation. The DMY of ewes in our experiment was higher compared to values published by Mioc et al. (2009), Antunac et al. (2011) and Hernandez et al. (2014) although different breeds or crossbreds were used in their research. On the contrary, Pellegrini et al. (1997) found a significantly higher DMY in Lacaune ewes in early lactation but the DMY values published by them were in the mid and late lactation lower compared to our results.

In sheep it is well-know that as lactation progresses the content of TS, F and TP in milk increase. These trends were also confirmed in our study in the content of TS, F and TP in milk which were comparable to those reported by Matutinovic et al. (2011) in Dalmatian Pramenka sheep, but higher than in

Table 1. Evaluation of curd quality

\begin{tabular}{cc}
\hline Class & Appearance and firmness of the curd and the appearance of whey \\
\hline 1 & $\begin{array}{c}\text { Appearance of curd is very good, curd firmness is high and the curd hold its shape perfectly after its } \\
\text { removal from Erlenmeyer flask. Whey is clear, of yellow-greenish colour. }\end{array}$ \\
\hline 2 & $\begin{array}{c}\text { Appearance of curd is good, curd firmness is lower and the curd not hold its shape perfectly. } \\
\text { Whey expulsion is not perfect, whey is whitish to greenish. }\end{array}$ \\
\hline 3 & Appearance of curd is average, curd firmness is very low, curd partly not hold its shape. \\
Whey is milky white.
\end{tabular}


Comisana ewes published by Sevi et al. (2004). On the other hand, Jaramillo et al. (2008) found higher content of TS, F and TP in Guirra and Manchega ewes. Above mentioned differences in both DMY as well as basic milk composition were mainly affected by nutrition and also by individual breeds, since their specific genetic structure leads to different morphological traits and production parameters. Moreover, specific husbandry conditions could also play an important role. The correlations between DMY and content of TS, F and TP, respectively, were significantly negative in all cases (Table 3), what is in accordance with the data published by Ochoa-Cordero et al. (2002) and Mioc et al. (2009). In contrast to F and TP content, the content of lactose decreased during lactation in our research. This trend is in accordance with Pugliese et al. (2000) and Matutinovic et al. (2011), who also found a decrease of lactose within the course of the lactation. However, the decline of the lactose content in our study was relatively low. The lactose content during lactation ranged from 4.99 to $4.58 \%$, which is comparable with Kuchtik et al. (2008) and Kondyli et al. (2012). All correlations between lactose and TS, F and TP were significantly negative which is in agreement with Mioc et al. (2009).
The contents of $\mathrm{Ca}$ and $\mathrm{P}$ were constantly growing throughout our study; in the case of $\mathrm{Ca}$, it is consistent with trends published by Pellegrini et al. (1997) and Abilleira et al. (2010). In contrast, Sevi et al. (2004) reported a stable levels of Ca and $\mathrm{P}$ contents during lactation, whilst, Aganga et al. (2002) found a stable decrease of content of both minerals. In general, mineral content of sheep milk seem to vary much more than those of cow milk (Rincon et al., 1994) due to feeding differences and seasonal lactation. However, in our opinion a gradual increase of the content of $\mathrm{Ca}$ and $\mathrm{P}$ during lactation was mainly affected by gradual increase of TP and casein contents which was confirmed by their correlation values. Polychroniadou and Vafopoulou (1985) also reported that the content of Ca is affected by the contents of total protein and casein. The content of both minerals in our experiment were higher than published by Khan et al. (2006) while Ca content was lower and $\mathrm{P}$ content was higher than those reported by Sevi et al. (2004). The Ca/P ratio declined $(\mathrm{p}<0.01)$ continuously from 1.14 to 1.07 with the advancing of lactation. Nevertheless, the $\mathrm{Ca} / \mathrm{P}$ ratio was optimal and always higher than 1 during the whole lactation.

Table 2. The effect of the lactation stage on daily milk yield, physico-chemical parameters of milk, somatic cell count, coagulation time and curd quality

\begin{tabular}{|c|c|c|c|c|c|c|c|}
\hline \multirow{2}{*}{ Trait } & \multicolumn{5}{|c|}{ Mean day of lactation } & \multirow{2}{*}{ Range } & \multirow{2}{*}{ SEM } \\
\hline & 57 & 92 & 127 & 162 & 197 & & \\
\hline DMY (L) & $1.07^{\mathrm{a}}$ & $0.89^{a b}$ & $0.94^{\mathrm{ab}}$ & $1.03^{a}$ & $0.77^{b}$ & $0.30-1.60$ & 0.027 \\
\hline TS (\%) & $17.61^{\mathrm{A}}$ & $18.74 \mathrm{AB}$ & $18.61 \mathrm{AB}$ & $18.74^{\mathrm{AB}}$ & $19.48^{\text {B }}$ & $15.86-22.19$ & 0.131 \\
\hline Fat (\%) & $6.25^{\mathrm{Aa}}$ & $7.68^{\mathrm{B}}$ & $7.48^{\mathrm{ABb}}$ & $7.56^{\mathrm{B}}$ & $7.69^{\mathrm{B}}$ & $4.56-9.82$ & 0.118 \\
\hline $\mathrm{TP}(\%)$ & $5.48^{\mathrm{A}}$ & $5.52^{\mathrm{A}}$ & $5.53^{\mathrm{A}}$ & $5.70^{\mathrm{A}}$ & $6.26^{\mathrm{B}}$ & $4.71-7.43$ & 0.051 \\
\hline Casein $(\%)$ & $4.02^{\mathrm{A}}$ & $4.12^{\mathrm{A}}$ & $4.13^{\mathrm{A}}$ & $4.28^{\mathrm{ABa}}$ & $4.76^{\mathrm{Bb}}$ & $3.21-5.68$ & 0.049 \\
\hline Lactose (\%) & $4.99^{\mathrm{A}}$ & $4.87^{\mathrm{ABa}}$ & $4.75^{\mathrm{ABCb}}$ & $4.58^{\mathrm{C}}$ & $4.64^{\mathrm{BCc}}$ & $4.16-5.28$ & 0.027 \\
\hline $\mathrm{Ca}(\mathrm{mg} / \mathrm{L})$ & $1365.7^{\mathrm{A}}$ & $1379.8^{\mathrm{ABa}}$ & $1410.1^{\mathrm{ABb}}$ & $1447.4^{\mathrm{BCb}}$ & $1515.7^{\mathrm{Cc}}$ & $1285-1657$ & 0.814 \\
\hline $\mathrm{P}(\mathrm{mg} / \mathrm{L})$ & $1199.5^{\mathrm{A}}$ & $1250.6^{\mathrm{ABa}}$ & $1294.1^{\mathrm{B}}$ & $1311.8^{\mathrm{Bb}}$ & $1419.5^{\mathrm{C}}$ & $1158-1611$ & 0.965 \\
\hline $\mathrm{Ca} / \mathrm{P}$ & $1.14^{\mathrm{A}}$ & $1.10^{\mathrm{AB}}$ & $1.09^{\mathrm{AB}}$ & $1.10^{\mathrm{AB}}$ & $1.07^{\mathrm{B}}$ & $0.96-1.24$ & 0.006 \\
\hline $\mathrm{pH}$ & 6.5 & 6.4 & 6.4 & 6.4 & 6.5 & $6.1-6.8$ & 0.01 \\
\hline $\mathrm{TA}\left({ }^{\circ} \mathrm{SH}\right)$ & 9.0 & 9.7 & 9.6 & 9.5 & 10.0 & $6.6-11.8$ & 0.13 \\
\hline $\operatorname{SCC}\left(10^{3} / \mathrm{mL}\right)$ & 87.72 & 91.50 & 126.56 & 122.00 & 130.22 & $36.00-420.00$ & 7.223 \\
\hline $\mathrm{CT}(\mathrm{s})$ & $165^{\mathrm{ab}}$ & $143^{a}$ & $147^{a b}$ & $179^{a b}$ & $188^{b}$ & $102-411$ & 4.6 \\
\hline CQ & 1.00 & 1.22 & 1.00 & 1.22 & 1.17 & $1.00-3.00$ & 0.041 \\
\hline
\end{tabular}

TS: total solids; TP: total protein; TA: titratable acidity; SCC: somatic cell count; CT: coagulation time; CQ: curd quality; DMY: daily milk yield. On the row different letters are significant at $\mathrm{p}<0.05$; capital different letters are significant at $\mathrm{p}<0.01$ 
The $\mathrm{pH}$ values were very stable during lactation and the stage of lactation did not have any significant effect on this parameter. This is in line with results given by Barron et al. (2001). The correlations between $\mathrm{pH}$ and all the other parameters were also insignificant. In contrast, Pavic et al. (2002) and Kuchtík et al. (2008) found a significant correlation between $\mathrm{pH}$ and TA. The TA values in sheep and goat milk are significantly influenced by protein content (Novotna et al., 2009), the higher the TP content, the higher the TA and vice versa. The same trend was also found in our study, but the stage of lactation did not have any significant effect on TA values.

All ewes in our study were under permanent veterinary supervision and no clinical signs of mastitis were observed. This fact was reflected in relatively low mean values of SCC with respect to the lactation stage (Table 2). The limit for subclinical mastitis in sheep (Bianchi et al., 2004) which is $500,000 \mathrm{SCC} / \mathrm{mL}$, was not exceeded in any individual sample. Nevertheless, SCC in our experiment insignificantly grew as lactation advanced what is in line with Jaramillo et al. (2008). On the other hand Paape et al. (2007) and Matutinovic et al.
(2011) reported a significant increase of SCC during lactation. In our opinion, the insignificant increase of SCC during lactation could be linked with a reduced milk yield or a functional alteration of the mammary gland tissue caused by the shorter survival of epithelial cells that are supplied with fewer nutrients at the end of the lactation as it is published by Sevi et al. (1999). Significant positive correlations were found between SCC and the content of TS, F, TP, casein and lactose, which correspond with results found by Matutinovic et al. (2011). In our opinion these positive correlations are probably an effect of lactation stage and not an effect of intramammary infections because the SCC were below the thresholds proposed to detect infected halves.

The stage of lactation had a significant effect on coagulation time (CT), which was extended with advanced lactation (with the exception of the first sampling). This corresponds to the results given by Jaramillo et al. (2008) and Abilleira et al. (2010). On the other hand, Jelínek et al. (1990) reported that from 90th day of lactation the CT gradually shortened till the end of lactation. In our opinion, elongation of CT in our study was mainly influenced by the gradual increase of the contents of TP, casein

Table 3. Phenotypic correlations of all traits of the study

\begin{tabular}{|c|c|c|c|c|c|c|c|c|c|c|c|c|c|c|}
\hline & $\mathrm{TP}$ & Fat & $\mathrm{TP}$ & Casein & Lactose & $\mathrm{Ca}$ & $\mathrm{P}$ & $\mathrm{Ca} / \mathrm{P}$ & $\mathrm{pH}$ & $\mathrm{TA}$ & SCC & $\mathrm{CT}$ & CQ & DMY \\
\hline TS & 1.00 & $0.90^{* *}$ & $0.66^{* *}$ & $0.53^{* *}$ & $-0.45^{* *}$ & $0.34^{* *}$ & $0.29^{* *}$ & -0.03 & -0.20 & 0.18 & $0.41^{* *}$ & 0.20 & -0.05 & $-0.46^{* *}$ \\
\hline Fat & & 1.00 & $0.33^{* *}$ & $0.26^{*}$ & $-0.61^{* *}$ & $0.30^{* *}$ & 0.16 & 0.09 & -0.21 & 0.10 & $0.36^{* *}$ & 0.05 & 0.03 & $-0.42^{* *}$ \\
\hline $\mathrm{TP}$ & & & 1.00 & $0.82^{* *}$ & $-0.23^{*}$ & $0.34^{* *}$ & $0.44^{* *}$ & $-0.25^{*}$ & 0.07 & $0.35^{* *}$ & $0.36^{* *}$ & $0.42^{* *}$ & -0.06 & $-0.29^{* *}$ \\
\hline Casein & & & & 1.00 & -0.15 & $0.27^{*}$ & $0.37^{* *}$ & $-0.23^{*}$ & 0.04 & $0.26^{*}$ & $0.30^{* *}$ & $0.35^{* *}$ & -0.04 & -0.15 \\
\hline Lactose & & & & & 1.00 & $-0.37^{* *}$ & $-0.22^{*}$ & -0.08 & 0.09 & -0.17 & $-0.32^{* *}$ & -0.13 & -0.05 & $0.31^{* *}$ \\
\hline $\mathrm{Ca}$ & & & & & & 1.00 & $0.67^{* *}$ & 0.16 & -0.07 & 0.02 & 0.10 & $0.29^{* *}$ & 0.16 & $-0.30^{* *}$ \\
\hline $\mathrm{P}$ & & & & & & & 1.00 & $-0.62^{* *}$ & 0.03 & 0.11 & 0.12 & 0.14 & 0.06 & $-0.29^{* *}$ \\
\hline $\mathrm{Ca} / \mathrm{P}$ & & & & & & & & 1.00 & -0.11 & -0.13 & -0.07 & 0.09 & 0.07 & 0.06 \\
\hline $\mathrm{pH}$ & & & & & & & & & 1.00 & 0.13 & -0.01 & -0.01 & 0.04 & 0.08 \\
\hline $\mathrm{TA}$ & & & & & & & & & & 1.00 & 0.18 & -0.01 & 0.07 & $-0.26^{*}$ \\
\hline $\mathrm{SCC}$ & & & & & & & & & & & 1.00 & 0.21 & 0.03 & -0.15 \\
\hline $\mathrm{CT}$ & & & & & & & & & & & & 1.00 & $0.40^{* *}$ & 0.13 \\
\hline CQ & & & & & & & & & & & & & 1.00 & 0.06 \\
\hline DMY & & & & & & & & & & & & & & 1.00 \\
\hline
\end{tabular}

${ }^{* *} \mathrm{p}<0.01 ;{ }^{*} \mathrm{p}<0.05$

TS: total solids; TP: total protein; TA: titratable acidity; SCC: somatic cell count; CT: coagulation time; CQ: curd quality;

DMY: daily milk yield 
and $\mathrm{Ca}$ during lactation what is also confirmed by their significant positive correlations shown in table 3 . The same positive relations were reported by Pellegrini et al. (1997) and Abilleira et al. (2010). Furthermore, Bencini (2002) reported that $\mathrm{pH}$ of sheep milk is a factor of paramount importance of the rennet coagulation time, but in our study no significant correlation between these parameters was found.

As a contrast to CT, the CQ was not affected by the stage of lactation, although, in the second half of lactation the CQ was slightly worse than in the first half of lactation. This result is in accordance with Coulon et al. (1998). In our opinion, relatively balanced CQ throughout lactation were primarily associated with increasing of TP, casein and Ca contents, relatively stable $\mathrm{pH}$ and TA values, and finally also with low values of SCC. As for correlations between the CQ and all other parameters, these were, except for the CT, insignificant; nevertheless, the positive significant correlation between CT and CQ implies that the longer the CT the better the CQ.

\section{Conclusion}

The stage of lactation significantly affected almost all monitored milk traits with the exception of $\mathrm{pH}, \mathrm{TA}, \mathrm{SCC}$ and CQ. The content of total solids (TS), fat (F), total protein (TP), casein, $\mathrm{Ca}$ and $\mathrm{P}$ was increased, while daily milk yield and the content of lactose were decreased with the advancement of lactation. Many studies showed that milk coagulation properties and the curd quality are influenced by the content of TP, casein, F, Ca and P in milk, $\mathrm{pH}$ and titratable acidity of milk and SCC. In our study, all these parameters were in satisfactory relations (a stable $\mathrm{pH}$ and TA, low SCC, increasing content of TP, casein, F, Ca and P) what led to very good curd quality throughout lactation. Nevertheless, the CT was significantly influenced by the stage of lactation and significantly positively related to CQ. The CT elongated with increasing content of $\mathrm{TP}$, casein and $\mathrm{Ca}$. To some extent, an elongation of the CT could also be affected by the increasing of SCC, because the correlation between CT and SCC was close to the significance threshold. Finally, the results of this research showed that Lacaune ewes had a satisfactory milk yield and physico-chemical and technological characteristics of milk under relatively extensive nutrition.

\section{Acknowledgements}

This study was supported by the Research plan NAZV KUS QJ1230044.

\section{Promjene $i$ povezanost fizikalno-kemijskih pokazatelja, broja somatskih stanica $i$ kvalitete gruša tijekom laktacije ovaca Lacaune pasmine}

\section{Sažetak}

Cilj istraživanja bio je utvrditi promjene i povezanost fizikalno-kemijskih pokazatelja, broja somatskih stanica (BSS) i kvalitete gruša tijekom laktacije ovaca Lacaune pasmine. Istraživanje je provedeno na osamnaest ovaca druge laktacije na ekološkoj farmi u Valaškoj Bistrici (Republika Češka). Utvrđeno je da je stadij laktacije statistički značajno utjecao na gotovo sve istraživane pokazatelje osim na $\mathrm{pH}$, titracijsku kiselost, BSS i kvalitetu gruša. Sadržaj suhe tvari, masti, ukupnih proteina, kazeina, Ca i P se povećavao, a dnevna količina mlijeka i sadržaj laktoze su se smanjivali s trajanjem laktacije. Stadij laktacije imao je značajan utjecaj na vrijeme koagulacije koje se povećavalo s trajanjem laktacije. Produženje vremena koagulacije bilo je pozitivno povezano sa sadržajem suhe tvari, kazeina i Ca. Za razliku od tog, stadij laktacije nije značajno utjecao na kvalitetu gruša, kao što nisu ni utvrđene značajne korelacije između kvalitete gruša i ostalih pokazatelja, osim za vrijeme koagulacije $(r=0,40)$. Može se zaključiti da su ovce Lacaune pasmine imale zadovoljavajuću proizvodnju mlijeka te fizikalnokemijske i tehnološke pokazatelje mlijeka usprkos ekstenzivnoj ishrani.

Ključne riječi: ovčje mlijeko, laktacija, kemijski sastav, tehnološka svojstva, koagulacija mlijeka 


\section{References}

1. Abilleira, E., Virto, M., Najera, A.I., Salmeron, J., Albisu, M., Perez-Elortondo, F.J., Ruiz de Gordoa, J.C., de Renobales, M., Barron, J.R. (2010): Effects of seasonal changes in feeding management under part-time grazing on the evolution of the composition and coagulation properties of raw milk from ewes. Journal of Dairy Science 93, 3902-3909. https://doi.org/10.3168/jds.2009-2983

2. Aganga, A.A., Amarteifio, J.O., Nkile, N. (2002): Effect of stage of lactation on nutrient composition of Tswana sheep and goat's milk. Journal of Food Composition and Analysis 15, 533-543. https://doi.org/10.1016/S0889-1575(02)91061-6

3. Antunac, N., Samarzija, D., Mioc, B., Pecina, M., Bendelja, D., Barac, Z. (2011): Influence of paragenetic factors on production and chemical composition of Paska sheep milk. Mljekarstvo 61 (3), 226-233.

4. Barron, L.J.R., Fernandez de Labastida, E., Perea, S., Chavarri, F., Vega, C., Vicente, M.S., Torres, M.I., Najera, A.I., Virto, M., Santisteban, A., Perez Elortondo, J., Albisu, M., Salmeron, J., Mendia, C., Torre, P., Ibanez, F.C., Renobales, M. (2001): Seasonal changes in the composition of bulk raw ewe's milk used for Idiazabal cheese manufacture. International Dairy Journal 11, 771-778. https://doi.org/10.1016/S0958-6946(01)00120-0

5. Bencini, R. (2002): Factors affecting the clotting properties of sheep milk. Journal of the Science of Food and Agriculture 82, 705-719. https://doi.org/10.1002/jsfa.1101

6. Bianchi, L., Bolla, A., Budelli, E., Carovi, A., Fazoli, C., Pauselli, M., Duranti, E. (2004): Effect of udder health status and lactation phase on the characteristics of Sardinian ewe milk. Journal of Dairy Science 87, 2401-2408. https://doi.org/10.3168/jds.S0022-0302(04)73362-7

7. Coulon, J.B., Verdier, I., Pradel, P., Almena, M. (1998): Effect of lactation stage on the cheesemaking properties of milk and the quality of Saint-Nectairetype cheese. Journal of Dairy Research 65, 295-305. https://doi.org/10.1017/S002202999700277X

8. Coulon, J. B., Delacroix-Buchet, A., Martin, B., Pirisi, A. (2004): Relationships between ruminant management and sensory characteristics of cheeses: a review. Le Lait 84, 221-241. https://doi.org/10.1051/lait:2004008

9. Gonzalo, C., Ariznabarreta, A., Carriedo, J.A., San Primitivo, F. (2002): Mammary pathogens and their relationship to somatic cell count and milk yield losses in dairy ewes. Journal of Dairy Science 85, 1460-1467. https://doi.org/10.3168/jds.S0022-0302(02)74214-8

10. Haenlein, G.F., Wendorff, W.L. (2008): Sheep Milk. In: Park Y.W., Haenlein, G.F.W. Handbook of Milk of NonBovine Mammals. Blackwell Publishing Professional, Iowa, USA, 137-194.

11. Hernandez, J.C.A., Ortega, O.A.C., Perez, A.H.R., Ronquillo, M.G. (2014): Effects of crossbreeding on milk production and composition in dairy sheep under organic management. Animal Production Science 54, 1641-1645. https://doi.org/10.1071/AN14214
12. Jaramillo, D.P., Zamora, A., Guamis, B., Rodrigues, M., Trujillo, A.J. (2008): Cheesemaking aptitude of two Spain dairy ewe breeds: Changes during lactation and relationships between physico-chemical and technological properties. Small Ruminant Research 78, 48-55. https://doi.org/10.1016/j.smallrumres.2008.04.005

13. Jelinek, P., Gajdusek, S., Illek, J., Helanova, I., Hlusek, J. (1990): Changes in composition and characteristics of ewe milk during lactation. Czech Journal of Animal Science 35, 803-815 (in Czech).

14. Khan, Z.I., Ashraf, M., Hussain, A., McDowell, L.R., Ashraf, M.Y. (2006): Concentrations of minerals in milk of sheep and goats grazing similar pastures in a semiarid region of Pakistan. Small Ruminant Research 65, 274-278. https://doi.org/10.1016/j.smallrumres.2005.07.050

15. Kondyli, E., Svarnas, C., Samelis, J., Katsiari, M.C. (2012): Chemical composition and microbiological quality of ewe and goat milk of native Greek breeds. Small Ruminant Research 103, 194-199. https://doi.org/10.1016/j.smallrumres.2011.09.043

16. Kuchtik, J., Sustová, K., Urban, T., Zapletal, D. (2008): Effect of the stage of lactation on milk composition, its properties and the quality of rennet curdling in East Friesian ewes. Czech Journal of Animal Science 53, 55-63.

17. Leitner, G., Chaffer, M., Shamay, A., Shapiro, F., Merin, U., Ezra, E., Saran, A., Silanikove, N. (2004): Changes in milk composition as affected by subclinical mastitis in sheep. Journal of Dairy Science 87, 46-52. https://doi.org/10.3168/jds.S0022-0302(04)73140-9

18. Matutinovic, S., Kalit, S., Salajpal, K., Vrdoljak, J. (2011): Effects of flock, year and season on the quality of milk from an indigenous breed in the sub-Mediterranean area. Small Ruminant Research 100, 159-163. https://doi.org/10.1016/j.smallrumres.2011.06.009

19. Mioc, B., Prpic, Z., Antunac, N., Antunovic, Z., Samarzija, D., Vnucec, I., Pavic, V. (2009): Milk yield and quality of Cres sheep and their crosses with Awassi and East Friesian sheep. Mljekarstvo 59, 217-224.

20. Novotna, L., Kuchtik, J., Sustova, K., Zapletal, D., Filipcik, R. (2009): Effects of lactation stage and parity on milk yield, composition and properties of organic sheep milk. Journal of Applied Animal Research 36, 71-76. https://doi.org/10.1080/097121 19.2009.9707034

21. Ochoa-Cordero, M.A., Torres-Hernandez, G., OchoaAlfaro, A.E., Vega-Roque, L., Mandeville, P.B. (2002): Milk yield and composition of Rambouillet ewes under intensive management. Small Ruminant Research 43, 269-274. https://doi.org/10.1016/S0921-4488(02)00019-6

22. Paape, M.J., Wiggans, G.R., Bannerman, D.D., Thomas, D.L., Sanders, A.H., Contreras, A., Moroni, P., Miller, R.H. (2007): Monitoring goat and sheep milk somatic cell counts. Small Ruminant Research 68, 114-125. https://doi.org/10.1016/j.smallrumres.2006.09.014

23. Park, Y.W.M., Juarez, M., Ramos, M., Haenlein, G.F.W. (2007): Physico-chemical characteristics of goat and sheep milk. Small Ruminant Research 68, 88-113. https://doi.org/10.1016/j.smallrumres.2006.09.013 
24. Pavic, V., Antunac, N., Mioc, B., Ivankovic, A., Havranek, J.L. (2002): Influence of stage of lactation on the chemical composition and physical properties of sheep milk. Czech Journal of Animal Science 47, 80-84.

25. Pellegrini, O., Remeuf, F., Rivemale, M., Barillet, F. (1997): Renneting properties of milk from individual ewes: influence of genetic and non-genetic variables, and relationship with physicochemical characteristics. Journal of Dairy Research 64, 355-366. https://doi.org/10.1017/S0022029997002203

26. Pirisi, A., Lauret, A., Dubeuf, J.P. (2007): Basic and incentive payments for goat and sheep milk in relation to quality. Small Ruminant Research 68, 167-178. https://doi.org/10.1016/j.smallrumres.2006.09.009

27. Polychroniadou, A., Vafopoulu, A. (1985): Variations of major mineral constituents of ewe milk during lactation. Journal of Dairy Science 68, 147-150. https://doi.org/10.3168/jds.S0022-0302(85)80808-0
28. Pugliese, C., Acciaioli, A., Rapaccini, S., Parisi, G., Franci, O. (2000): Evolution of chemical composition, somatic cell count and renneting properties of the milk of Massese ewes. Small Ruminant Research 35, 71-80. https://doi.org/10.1016/S0921-4488(99)00070-X

29. Rincon, F., Moreno, R., Zurera, G., Amaro, M. (1994): Mineral composition as a characteristic for the identification of animal origin of raw milk. Journal of Dairy Research 61, 151-154. https://doi.org/10.1017/S0022029900028144

30. Sevi, A., Albenzio, M., Taibi, L., Dantone, D., Massa, S., Annicchiarico, G. (1999): Changes of somatic cell count through lactation and their effects on nutritional renneting and bacteriological characteristics of ewe's milk. Advances in Food Sciences 21, 122-127.

31. Sevi, A., Albenzio, M., Marino, R., Santillo, A., Muscio, A. (2004): Effect of lambing season and stage of lactation on ewe milk quality. Small Ruminant Research 51, 251-259. https://doi.org/10.1016/S0921-4488(03)00196-2 